\title{
Shedding of APP limits its synaptogenic activity and cell adhesion properties
}

\section{Ronny Stahl ${ }^{1,2 \dagger}$, Sandra Schilling ${ }^{3 \dagger}$, Peter Soba ${ }^{1,4}$, Carsten Rupp ${ }^{3}$, Tobias Hartmann ${ }^{5}$, Katja Wagner ${ }^{1,3}$, Gunter Merdes ${ }^{1,6}$, Simone Eggert ${ }^{3 \dagger}$ and Stefan Kins ${ }^{1,3,5 * t}$}

${ }^{1}$ Center of Molecular Biology ZMBH, University of Heidelberg, Heidelberg, Germany

${ }^{2}$ Department of Physiological Genomics, Institute of Physiology, Ludwig-Maximilians University Munich, Munich, Germany

${ }^{3}$ Department of Human Biology and Human Genetics, Technical University of Kaiserslautern, Kaiserslautern, Germany

${ }^{4}$ Center for Molecular Neurobiology (ZMNH), University of Hamburg, Hamburg, Germany

${ }^{5}$ Deutsches Institut für DemenzPrävention, Experimental Neurology, Saarland University, Homburg/Saar, Germany

${ }^{6}$ Department of Biosystems Science and Engineering, ETH Zürich, Basel, Switzerland

Edited by:

Rakez Kayed, University of Texas

Medical Branch, USA

Reviewed by:

Zilai Wang, UT Southwestern

Medical Center at Dallas, USA

Colin Masters, The Florey Institute,

Australia

*Correspondence:

Stefan Kins, Department of Human

Biology and Human Genetics,

Technical University of

Kaiserslautern, Erwin Schrödinger

StraßeGeb. 13, 67663

Kaiserslautern, Germany

e-mail: s.kins@biologie.uni-kl.de

${ }^{+}$These authors have contributed

equally to this work.
The amyloid precursor protein (APP) plays a central role in Alzheimer's disease (AD) and has essential synapse promoting functions. Synaptogenic activity as well as cell adhesion properties of APP presumably depend on trans-cellular dimerization via its extracellular domain. Since neuronal APP is extensively processed by secretases, it raises the question if APP shedding affects its cell adhesion and synaptogenic properties. We show that inhibition of APP shedding using cleavage deficient forms of APP or a dominant negative $\alpha$-secretase strongly enhanced its cell adhesion and synaptogenic activity suggesting that synapse promoting function of APP is tightly regulated by $\alpha$-secretase mediated processing, similar to other trans-cellular synaptic adhesion molecules.

Keywords: Alzheimer's disease, amyloid precursor protein, APP processing, cell adhesion, SAM, synaptogenic activity

\section{INTRODUCTION}

A new era of Alzheimer's disease (AD) research began with identification of the Amyloid- $\beta(A \beta)$ peptide as a major amyloid plaque component (Masters et al., 1985). Amyloid- $\beta$ is derived from the amyloid precursor protein (APP; Kang et al., $1987)$ by sequential cleavages of $\beta$ - and $\gamma$-secretase. In the amyloidogenic pathway, $\beta$-secretase (BACE1) cleavage releases the large ectodomain of APP ( membrane-anchored C-terminal APP fragment ( $\beta$-CTF; Vassar et al., 1999). Cleavage of $\beta$-CTF by $\gamma$-secretase leads to the secretion of $A \beta$ peptides of various lengths and the release of the APP intracellular domain (AICD) into the cytosol (Weidemann et al., 2002; Kakuda et al., 2006). Alternatively, APP can first be cleaved in the non-amyloidogenic pathway by $\alpha$-secretase within the $\mathrm{A} \beta$ domain (Esch et al., 1990). In neurons, this cleavage is mainly mediated by the protease ADAM10 (Kuhn et al., 2010; Prox et al., 2013) and releases the APP ectodomain $(\operatorname{sAPP} \alpha)$ while generating the membrane-bound C-terminal fragment $(\alpha-C T F)$. The latter can be further processed again by the $\gamma$-secretase complex, resulting in the secretion of a $3-\mathrm{kDa}$ fragment (p3) and the release of AICD (Weidemann et al., 2002).

Amyloid precursor protein is part of a larger gene family, which includes two mammalian homologs, the amyloid precursor like protein 1 and 2 (APLP1 and APLP2; Walsh et al., 2007; Jacobsen and Iverfeldt, 2009). It has been shown that all APP family members can dimerize in a homo- and heterotypic manner in cis- and in trans-orientation (Soba et al., 2005; Kaden et al., 2009). All APP family members across different species including D. melanogaster (APPL) share similar domain architectures (Luo et al., 1990). Accordingly, the large extracellular domain contains the highly conserved E1 and E2 domains, which are connected by an acidic domain (Reinhard et al., 2005; Soldano and Hassan, 2014). The E1 domain was identified as the major interaction interface for homo- and heterodimerization of APP, APLP1 and APLP2 (Soba et al., 2005; Kaden et al., 2009; Dahms et al., 2010) suggesting a function of APP in cell adhesion (Herms et al., 2004; Young-Pearse et al., 2007).

Aged mice of APP single knockouts show impairment in spatial learning (Müller et al., 1994; Phinney et al., 1999; Ring et al., 2007) and long-term potentiation (Seabrook et al., 1999; Ring et al., 2007; Tyan et al., 2012). Furthermore, a reduced number of dendritic spines (Lee et al., 2010; Tyan et al., 2012; Weyer et al., 2014) and a reduced overall dendritic length in the CA1 region has been reported (Seabrook et al., 1999). APP/APLP2 double knockout (dko) mice die shortly after birth and display profound neuronal defects in the central and peripheral nervous system. 
Analysis of the neuromuscular junction (NMJ) revealed incomplete apposition of the pre- and postsynaptic structures (Wang et al., 2005), a reduced number of docked presynaptic vesicles and an impaired synaptic transmission (Wang et al., 2005). Mice that express only sAPP $\alpha$ in an APP/APLP2 dko background show less pronounced, but also severe defects in the peripheral as well as in the central nervous system, including motor and learning deficits (Weyer et al., 2011). This argues that $\operatorname{sAPP} \alpha$, although representing the major secreted species of APP, only partially rescues APP function. Notably, APP family members are expressed pre- and postsynaptically (Kim et al., 1995; Lyckman et al., 1998; Back et al., 2007; Hoe et al., 2009; Wang et al., 2009; Wilhelm et al., 2014), a prerequisite for synaptic adhesion molecules (Siddiqui and Craig, 2011; Baumkötter et al., 2012). A recent publication showed APP to be predominantly located at the surface of synaptosomes (Wilhelm et al., 2014). Further, tissue specific deletion of APP in either presynaptic motor neurons or postsynaptic muscle cells in APLP2-/- mice demonstrated similar NMJ defects as observed in APP/APLP2 dko mice (Wang et al., 2009). In conclusion neither sAPP nor expression of APP only at the pre- or postsynaptic site is sufficient for proper formation of the NMJ.

In line with these analyses, co-culture assays of a non-neuronal cell line seeded on primary neurons (Biederer and Scheiffele, 2007) revealed that expression of APP in non-neuronal cells promotes presynaptic differentiation of contacting axons (Wang et al., 2009; Baumkötter et al., 2014), similar to Neuroligin1 (NLG-1; Scheiffele et al., 2000; Wang et al., 2009). Synapse promoting activity of APP in the hemisynaptic assay depends on expression of APP containing the E1 domain on both sides, similarly to what was shown for cell adhesion properties of APP (Soba et al., 2005; Wang et al., 2009; Dahms et al., 2010).

Recent publications suggest that the synaptogenic activity of synaptic adhesion molecules (SAM) is regulated by ectodomain shedding (Suzuki et al., 2012; Pettem et al., 2013). Since APP is heavily processed by secretases, we investigated the influence of proteolytic processing on trans-interaction properties of APP and its effect on APP synaptogenic function.

\section{RESULTS}

\section{GENERATION OF SECRETION DEFICIENT APP MUTANTS}

We have previously shown using a Schneider (S2) cell based aggregation assay (Tsiotra et al., 1996; Klueg and Muskavitch, 1999; Islam et al., 2004) that APP possesses adhesion properties and can induce cellular aggregation (Soba et al., 2005). To investigate the consequences of $\alpha$-secretase processing on APP-mediated cell adhesion, we designed different putative secretion deficient APP mutants: N-terminally myc-tagged APP carrying either an amino acid substitution (F615P) previously shown to lower $\alpha$-secretase cleavage (Sisodia, 1992), small deletions removing the $\alpha$-secretase and $\beta$-secretase cleavage site (APP $\Delta$ F616, APP $\Delta$ S622), and deletion of $A \beta_{10-24}$ including amino acid substitutions with aspartates to increase electrostatic repulsion of $\alpha$-secretase (APP-D8; Figure 1A).

To test shedding deficiency of these different APP mutants, S2 cells were transfected and $\mathrm{SAPP}$ total was analyzed (Figure 1B). All investigated APP mutants showed a significant reduction in $\mathrm{sAPP}_{\text {total }}$ generation while cellular APP amounts were only moderately increased, likely due to reduced processing (Figure 1C). The strongest effect on $\mathrm{sAPP}_{\text {total }}$ secretion with an approximately $60 \%$ reduction was observed for APP-D8. These data suggest that deletion of the APP cleavage sites or interference with $\alpha$-secretase substrate binding by electrostatic repulsion efficiently reduces APP processing.

\section{SECRETION DEFICIENT APP ACCELERATES CELL CLUSTERING}

To investigate if reduced APP processing affects cell adhesion, we next analyzed the secretion deficient mutants of APP in a previously used S2 cell aggregation assay (Soba et al., 2005; Figures 1D,E). Strikingly, all secretion-impaired forms of APP induced significantly increased cell clustering (Figures 1D,E). We observed a more than two-fold increase in clustered cells expressing the secretion-deficient constructs APP-D8, APP $\Delta$ F616 and APP $\triangle$ S622 compared to APPwt expressing cells. Consistent with its weaker inhibition of APP cleavage, the smallest increase in clustering-ability was observed in APP-F615P expressing cells. To further validate these results, we inhibited $\alpha$-secretase cleavage by co-expression of a dominant-negative form of Kuz ${ }^{\mathrm{DN}}$ (Pan and Rubin, 1997), the Drosophila ADAM10 homolog. Co-expression of Kuz ${ }^{\mathrm{DN}}$ together with APP in S2 cells caused strongly increased cell clustering (Figures 1D,E), comparable to that observed with cells expressing secretion-deficient APP mutants. Together these data confirm our hypothesis that inhibition of $\alpha$-secretase cleavage promotes APP-mediated trans-cellular adhesion.

\section{APP MEDIATED CELL ADHESION PROPERTIES ARE E1 DOMAIN DEPENDENT}

The APP E1 domain is believed to be the major interface mediating the trans-interaction of APP as APP lacking the E1 domain (APP $\triangle \mathrm{E} 1$ ) displayed reduced cell adhesion properties (Soba et al., 2005) and lower synaptogenic activity (Wang et al., 2009).

In order to analyze whether increased APP mediated cell-cell interaction caused by inhibition of $\alpha$-cleavage also depends on the E1 domain, we generated an APP mutant construct carrying both, a secretion deficient mutation and a deletion of the E1 domain (APP $\triangle$ E1-F615P; Figure 1F). S2 cells were transiently transfected with APP, APP $\triangle$ E1, APP-F615P or APP $\triangle \mathrm{E} 1-\mathrm{F} 615 \mathrm{P}$ and allowed to aggregate after induction of APP expression. Quantification of clustered APP expressing cells revealed that APP $\triangle \mathrm{E} 1$ or APP $\triangle \mathrm{E} 1-$ F615P induced significantly less cell clustering in comparison to wildtype APP (Figure 1G). Similarly, aggregated S2 cells coexpressing APP $\triangle \mathrm{E} 1$ together with $\mathrm{Kuz}^{\mathrm{DN}}$ showed significantly decreased cell clustering in comparison to cells co-expressing APP and $\mathrm{Kuz}^{\mathrm{DN}}$ (Figures 1F,G). These data validate our previous results showing that the E1 domain is required for APP mediated cell clustering. Moreover, it strongly suggests that increased cell clustering by inhibition of $\alpha$-secretase cleavage depends on transdimerization properties of APP and not other potential cell adhesion molecules expressed in S2 cells.

\section{PROCESSING OF SECRETION DEFICIENT APP MUTANTS IN MAMMALIAN CELLS}

To investigate if inhibition of APP processing also promotes APP trans-interaction properties in mammalian cells, we first analyzed proteolytic processing of the APP mutants APP $\triangle$ S622 
A

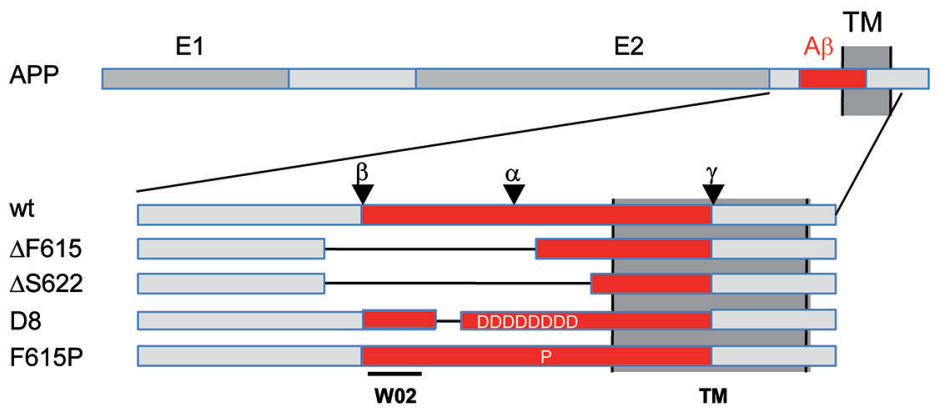

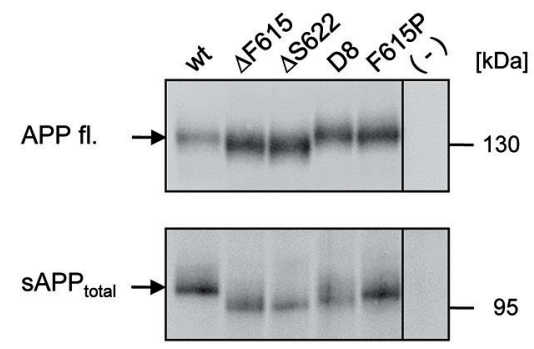

D
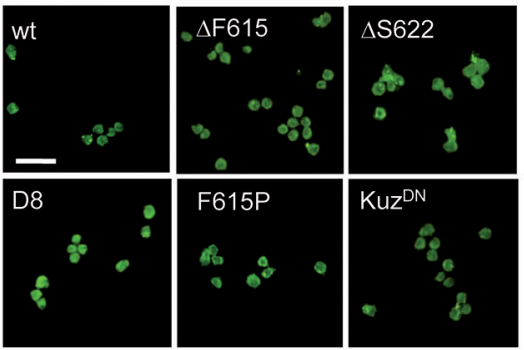

$\mathbf{F}$

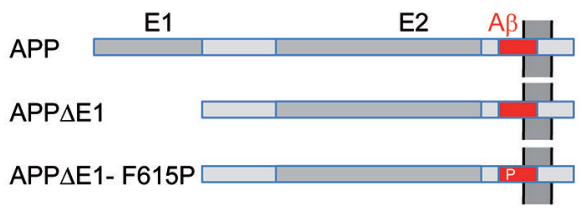

C

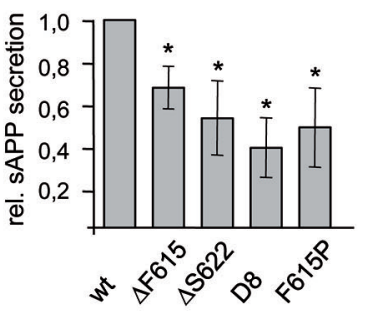

E

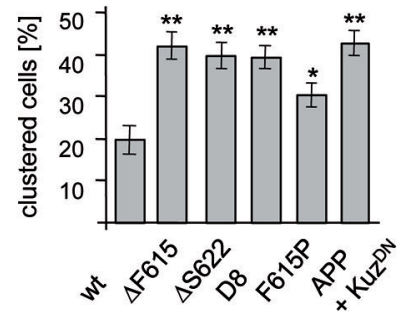

G

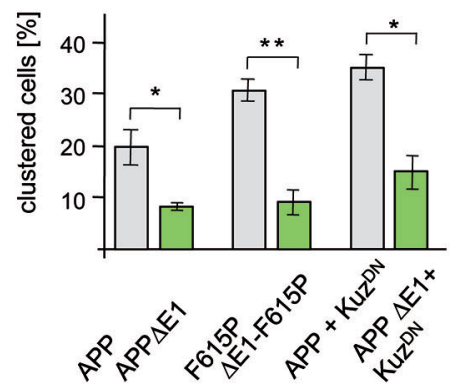

FIGURE 1 | Analysis of APP secretion deficient mutants in Drosophila S2 cells. (A) Schematic representation of N-terminally myc tagged APP secretion deficient constructs. The E1 and E2 domain as well as the transmembrane (TM) domain are highlighted in dark gray. The $A \beta$ region of APP (red) is shown enlarged and the position of deletions and amino acid substitutions is given. Additionally, positions of $\alpha-, \beta-$, and $\gamma$-cleavage sites are indicated as well as the epitope of antibody W02 (aa 2-8). Deletions of the APP mutants are marked with lines. (B) Western Blot analysis of SAPP total secretion from transfected S2 cells expressing APPwt and mutant variants. Direct load of cellular extracts and medium-IP (22734) samples were subjected to SDS-PAGE and immunoblotted with antibody 22C11. (C) Densitometric quantification of $s A P P_{\text {total }} / A P P$ fl. ratio ( $t$-test, $n \geq 3, \pm$ SEM). (D) S2 cells, transiently transfected with APPwt or secretion deficient APP-mutants were aggregated and immunostained with an anti c-myc antibody. Scale bar: $20 \mu \mathrm{m}$. (E) Quantification of clustered wild type APP and mutant APP expressing S2 cells ( $t$-test, $n \geq 5$; \pm SEM); $\left({ }^{*} p<0.05\right.$; $* *<0.001$; $\left.* * *<0.0001\right)$. (F) Scheme of APP mutants lacking the E1 domain. (G) S2 cells were transiently transfected with human APPwt or secretion deficient APP-F615P and the corresponding E1-deletion constructs (APP $\triangle$ E1, APP-F615P $\triangle$ E1) or co-transfected with APPwt or APP $\triangle \mathrm{E} 1$ and a dominant negative form of Kuzbanian $\left(\mathrm{Kuz}^{\mathrm{DN}}\right)$. Cells were aggregated and immunostained with anti c-myc antibody showing that secretion deficient APP cell-clustering depends on the E1-domain. Quantification of clustered cells given as percentage of the amount of transfected cells ( $t$-test, $n \geq 5 ; \pm$ SEM; ${ }^{*} p<0.05 ;{ }^{* *} p<0.001$; ** $p<0.0001$ ). 


$$
\text { A }
$$

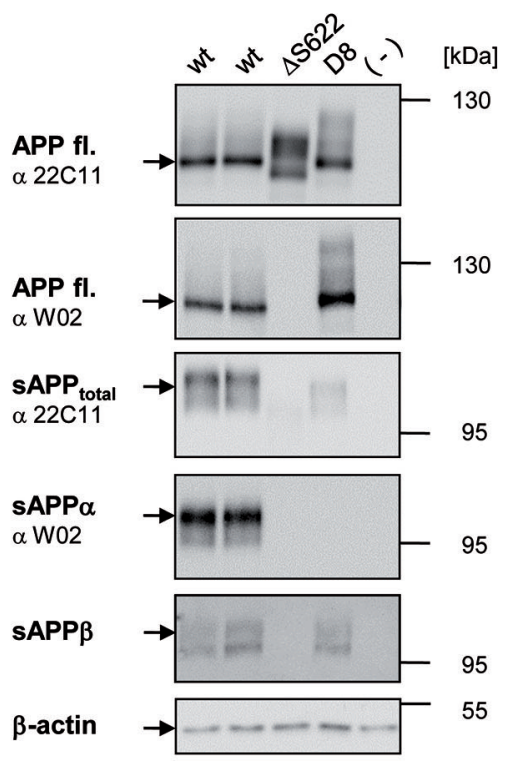

FIGURE 2 | Analysis of secretion deficient mutants in HEK293 cells. (A) Western Blot analysis of APP secretion deficient mutants. HEK293 cells were transiently transfected with APPwt and mutants APP 4622 and APP-D8. Cell lysates were analyzed with antibody $22 \mathrm{C} 11$ or W02 to detect full length APP via Western Blot. Medium samples of APP were analyzed with antibody 22C11 to detect SAPP total, antibody W02 to detect SAPP $\alpha$ and an SAPP $\beta$ specific antibody. Note, the W02 epitope is deleted in APP 622 . $\beta$-actin antibody served as a loading control. (B) Quantification of data
B
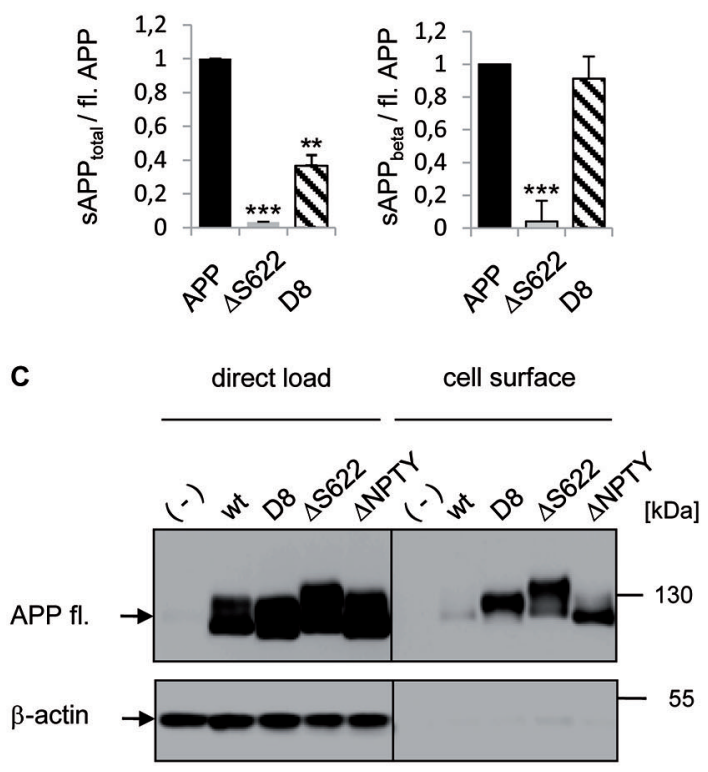

shown in panel (A). One-way ANOVA followed by Tukey's post hoc analyses $\left({ }^{*} p<0.05\right.$; * $p<0.001 ; * * * 0.0001, n=$

$5 \pm$ SEM). (C) Cell surface biotinylation of APP secretion deficient mutants. HEK293 cells were transfected with the indicated constructs. Direct load of cell lysates is documented in the left panel together with the $\beta$-actin loading control. In the right panel, APP cell surface levels after streptavidin immunoprecipitation and Western Blot detection with antibody c-myc is shown and $\beta$-actin as a negative control for intracellular proteins at the cell surface. and APP-D8 that displayed the strongest effect in Drosophila S2 cells (Figure 2). Expression of these APP forms in HEK293 cells followed by Western blotting detected appropriate expression (Figure 2A). Both APP mutations resulted in a highly significant reduction in $\mathrm{SAPP}_{\text {total }}$ secretion $(p<0.0001$; Figures $2 \mathrm{~A}, \mathbf{B})$. For $\mathrm{APP} \triangle \mathrm{S} 622, \mathrm{sAPP}_{\text {total }}$ levels were even stronger decreased than for APP-D8. For APP $\triangle$ S622 it is not possible to differentiate between sAPP $\alpha$ and sAPP $\beta$ secretion, as the corresponding region between the $\alpha$ - and $\beta$-cleavage sites was deleted. The low residual amount of sAPP total in case of APP-D8 was mainly caused by an impairment of $\alpha$-secretase cleavage, as shown by Western blot analysis with an antibody (W02) directed against the C-terminus of sAPP $\alpha$ (Ida et al., 1996; Figure 2A). W02 antibody binding to epitope 2-8 of the A $\beta$ sequence (Miles et al., 2008; Figure 1A) was not affected by the APP-D8 mutation as shown for full length APPD8 detection. Conversely, we observed no significant decrease in $\beta$-site cleavage for APP-D8 (Figures 2A,B). This indicates that exchanging amino acids surrounding the $\alpha$-cleavage site to aspartate residues nearly completely abolishes $\alpha$-secretase cleavage of APP without affecting $\beta$-secretase ectodomain shedding.

We hypothesized that the observed reduction in APP shedding should result in an increase of full length APP at the cell surface. Indeed, we detected strongly increased plasma membrane levels of shedding deficient APP-D8 and APP $\triangle$ S622 by cellsurface biotinylation experiments (Figure 2C). Cell surface levels were increased to a similar degree when using an internalization deficient APP lacking the NPTY motif (Figure 2C), suggesting that both, cleavage and internalization of APP contribute to its turnover and plasma membrane levels.

Together, these data show that APP cleavage site mutagenesis efficiently suppresses secretion in mammalian cells as well and results in accumulation of APP at the cell surface.

\section{APP SYNAPTOGENIC FUNCTION DEPENDS ON APP PROCESSING}

In previous studies using a mixed-culture system (Scheiffele et al., 2000; Graf et al., 2004; Biederer and Scheiffele, 2007), it has been shown that expression of APP in HEK293 cells causes recruitment of contacting axons from co-cultured primary neurons (Wang et al., 2009). We reproduced this analysis and validated the reported synaptogenic activity of APP to induce presynaptic differentiation of contacting axons as indicated by clustering of synaptophysin and SV2 at TAU-positive axon terminals (Figures 3A,B). To investigate the synaptogenic properties of processing-deficient mutant forms of APP, we transiently transfected NLG-1, wild-type APP (APP fL), APP-D8, APP $\triangle$ S622, as well as GFP in HEK293 cells. The transfected cells were then co-cultured with primary cortical neurons and assayed for their capacity to induce presynaptic differentiation. Neuroligin-1 expressing HEK293 cells served as a positive control (Scheiffele et al., 2000), while GFP expressing HEK293 cells 


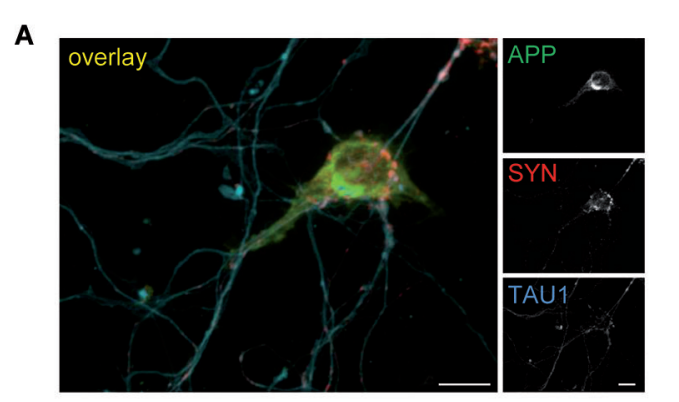

C

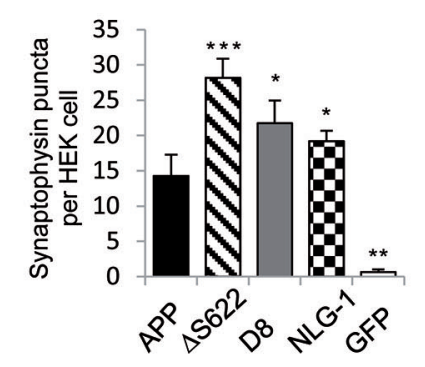

D

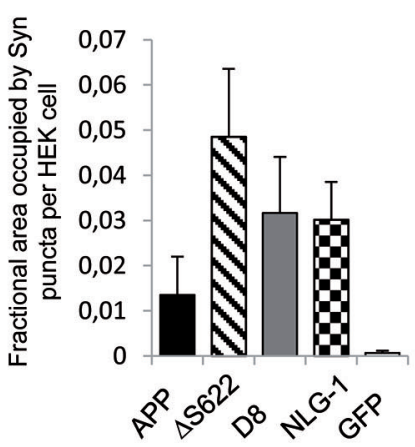

FIGURE 3 | APP processing deficient mutants show stronger synaptogenic activity than APPwt. The synaptogenic activity of APP was analyzed in a co-culture assay. HEK293 cells were transiently transfected with APPwt and seeded $24 \mathrm{~h}$ later on primary cortical neurons (DIV7). The cells were fixed after $24 \mathrm{~h}$ (neurons DIV 8) and analyzed via immunocytochemistry. (A) Cells were stained with TAU1 as axonal marker, Synaptophysin as presynaptic marker and antibody c-myc for APP. (B) HEK293 cells were transfected with NLG-1 as a positive control, GFP as a negative control,
B
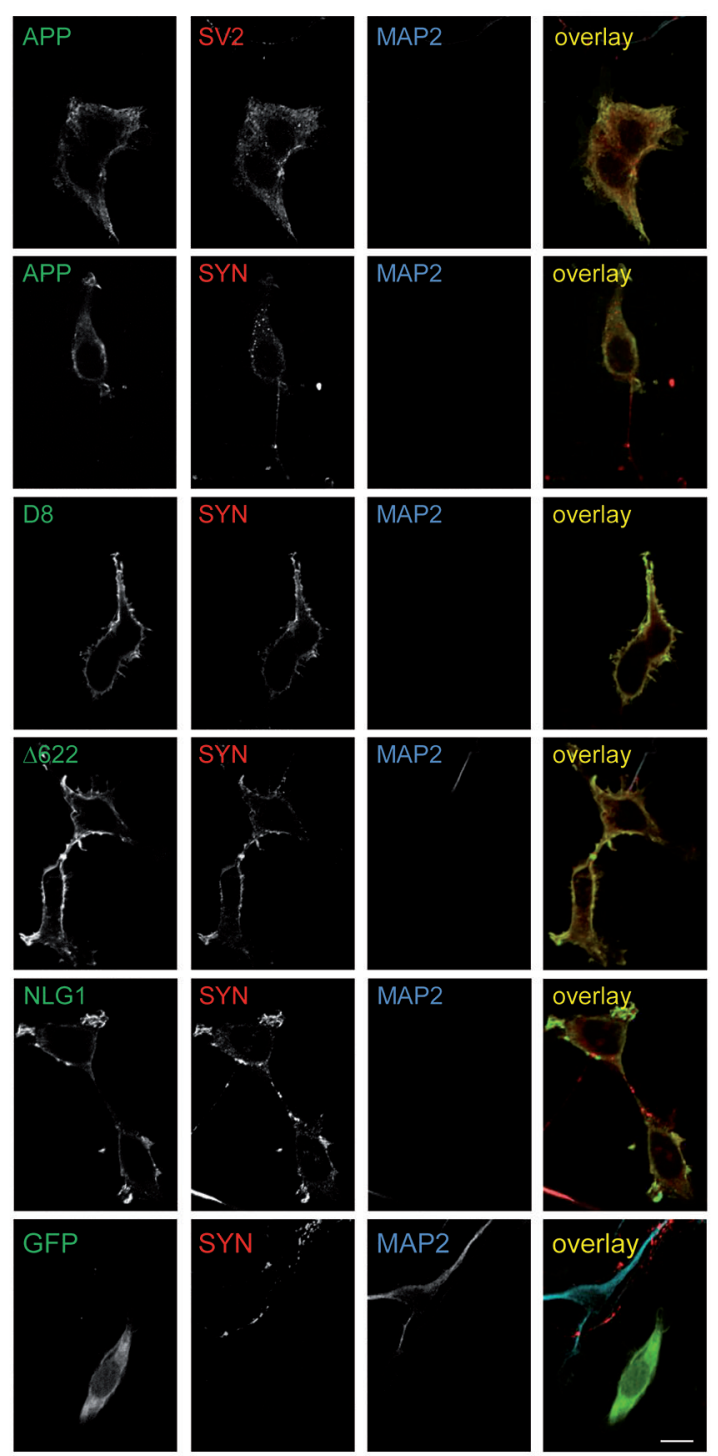

APPwt and APP processing deficient constructs. Cells were stained with antibody MAP2 as a dendritic marker and Synaptophysin or SV2 as a marker for presynaptic vesicles and antibody c-myc to visualize heterologously expressed APP. (C) Quantification of Synaptophysin positive puncta per HEK293 cell. (D) Quantification of Synatophysin covered area per HEK293 cell. Bars represent mean values \pm SEM of at least three independent experiments ( $n \geq 3$; one-way ANOVA; ${ }^{*} p<0.05$, * $p<0.01$, and *** $p<0.005$ compared to APP fl.). were used as a negative control (Figure 3B). Similarly to NLG1 , expression of APP but not GFP potently promoted synaptic puncta formation as measured by the number of Synaptophysin positive puncta and area covered per transfected HEK293 cell (Figures 3C,D). Interestingly, both processing deficient mutant APP forms promoted presynaptic differentiation of contacting axons to a much higher extent than APP wild-type, which in case of APP-D8 was even stronger than the synaptogenic activity of NLG-1. Taken together, these data corroborate our hypothesis that APP synaptogenic function is limited by the extent of APP shedding activity.

\section{DISCUSSION}

Trans-cellular dimerization of APP is assumed to mediate cell adhesion and synaptogenic activity, similar to NLG-1 and other synaptic cell adhesion molecules (Siddiqui and Craig, 2011; Baumkötter et al., 2012; Müller and Zheng, 2012). Here, we show that inhibition of processing promotes APP-mediated cell 
adhesion and synaptogenic properties, indicating that APP shedding negatively regulates trans-dimerization dependent physiological functions of APP.

Once APP reaches the plasma membrane, it normally undergoes rapid proteolytic conversion by sheddases (Lammich et al., 1999; Kuhn et al., 2010; Prox et al., 2013). Therefore, we expected that inhibition of APP processing would enhance APP transinteraction properties. To test this hypothesis we were using Schneider cells because of their semi-adherent characteristics and due to the fact that they don't express APPL endogenously. Our analysis of APP-mediated cell adhesion, using the Drosophila S2cell aggregation assay (Tsiotra et al., 1996; Islam et al., 2004; Soba et al., 2005) revealed that the extent of cell clustering increases with a decreased rate of mutant APP cleavage.

So far, the strongest inhibition of APP $\alpha$-secretase cleavage has been achieved in mammalian cells by introducing single amino acid exchanges V614G and F615P (Sisodia, 1992). We tested the F615P mutant in Drosophila and human cells and could validate the reduction in SAPP secretion (Figure 2). Interestingly, the highest extent of sAPP suppression was observed for the APP-D8 and APP $\triangle$ S622 mutants. In case of APP-D8, the mutation mostly affected $\alpha$ - but not $\beta$-secretase cleavage. In this case $\alpha$-secretase activity, which has been shown to exhibit low sequence specificity (Maruyama et al., 1991; Sahasrabudhe et al., 1992; Sisodia, 1992; Zhong et al., 1994), might be inhibited by electrostatic repulsion due to the introduced aspartate stretch. This strategy has been successfully used before to prevent metalloprotease cleavage of the Notch ligand Delta 1 (Six et al., 2003). Our data suggest a tight correlation between APP shedding and APP mediated cell-cell interaction. These results were validated by inhibition of $\alpha$-secretase activity using a dominant-negative variant of $\mathrm{Kuz}^{\mathrm{DN}}$ (Pan and Rubin, 1997). Expression of $\mathrm{Kuz}^{\mathrm{DN}}$ suppresses endogenous $\alpha$-secretase activity and thus concomitantly increased cell clustering of APPtransfected S2 cells. Dominant-negative Kuzbanian may also affect other ADAM10 substrates like E-Cadherin or CX3CL1 (Hundhausen et al., 2003; Maretzky et al., 2005), which possibly modulate S2 cell adhesion independent of APP. To exclude that $\mathrm{Kuz}^{\mathrm{DN}}$ expression elevated clustering of S2 cells in an APP independent manner, we used an APP construct lacking the E1 domain that is essential to mediate APP trans-cellular interactions. Amyloid precursor protein secretion deficient mutants containing the E1 deletion (APP $\Delta \mathrm{E} 1)$ as well as co-expression of APP $\triangle \mathrm{E} 1$ with $\mathrm{Kuz}^{\mathrm{DN}}$ showed a clear decrease in cell clustering, which was not significantly increased in comparison to cell clustering mediated by APP. The above studies provide clear evidence that reduced APP shedding promotes trans-directed APP interaction.

Notably, inhibition of APP shedding was more pronounced in mammalian than in S2 cells, suggesting similar, but non-identical cleavage preferences. In Drosophila, an ADAM-like protease is encoded by the Kuzbanian gene (KUZ, Rooke et al., 1996), which was shown to cleave Notch (Pan and Rubin, 1997), APP and APPL at the expected $\alpha$-secretase cleavage sites (Carmine-Simmen et al., 2009). In case of $\beta$-secretase the similarity between Drosophila and human cells seems to be lower. In mammals two closely related aspartic proteases, BACE1 ( $\beta$-site APP-cleaving enzyme;
Vassar et al., 1999) and BACE2 (Solans et al., 2000), have been identified. In Drosophila, two aspartic proteases were identified by their homology to human BACE (DASP1 and DASP2), but their $\beta$-secretase activity towards human APP or APPL discussed is controversial (Kotani et al., 2005; Carmine-Simmen et al., 2009; Poeck et al., 2012). For DASP2a it was reported that it cleaves APPL and APP in a BACE like manner at a position $\mathrm{N}$-terminal of Asp1 (A $\beta$ numbering) at the $\beta$-cleavage site, resulting in $\beta$-CTF- and $A \beta$ peptide-like cleavage products with an higher apparent molecular weight (Carmine-Simmen et al., 2009; Poeck et al., 2012). Possibly, cleavage of APP by DASP2, the postulated Drosophila BACE homolog, is not affected by the APP mutants used in our analysis. This might explain the higher residual generation of sAPP in Drosophila compared to mammalian cells.

To investigate the consequences of APP processing we used a well-established mixed co-culture system assaying the synaptogenic activity of cell adhesion molecules (Scheiffele et al., 2000; Graf et al., 2004; Biederer and Scheiffele, 2007). Comparable to NLG-1, expression of APP in HEK293 cells potently promoted synaptic puncta formation (Figure 3 ) as reported before by Wang et al. (2009). Both investigated processing deficient APP forms showed a significantly higher amount of Synaptophysin puncta and also an elevated fractional cell area covered by Synaptophysin on the transfected HEK293 cells (Figure 3). These data clearly show that reduced APP processing enhances its synaptogenic activity to an even higher extent than NLG-1, a bona fide SAM (Scheiffele et al., 2000; Sudhof, 2008).

Similarly, it has recently been shown that NLG-1 undergoes ectodomain shedding by ADAM10 (Suzuki et al., 2012). Interestingly, neuronal activity increased shedding of NLG-1 and thus might negatively regulate remodeling of spines (Suzuki et al., 2012). In line with this, also Calsyntenin 3 is subject to ectodomain shedding (Araki et al., 2004), whereas membrane anchored Calsyntenin 3 displays a higher synaptogenic activity than its secreted form (Pettem et al., 2013). Comparable mechanism could be in place for APP, as overexpression of APP induces dendritic spine formation (Lee et al., 2010), whereas loss of APP goes along with a reduced spine density and LTP defects, which can be only partially rescued by $\operatorname{sAPP} \alpha$ (Weyer et al., 2011). Interestingly, APP transgenic mice overexpressing human APP mutated at the $\alpha$-secretase cleavage site show a phenotype of decreased sensitivity to NMDA, a sign of NMDA receptor hypofunction and misregulated synapse formation as well as epileptic seizures (Moechars et al., 1996, 1998). Furthermore, processing of APP and sAPP secretion was shown to be increased by synaptic activity (Farber et al., 1995). In turn, APP cleavage products also affect neurotransmission (Furukawa and Mattson, 1998; Kamenetz et al., 2003; Taylor et al., 2008; Weyer et al., 2011; Wilhelm et al., 2014). Although the complex interplay of these different functions of APP and its cleavage products is not yet understood, our data suggest that APP processing negatively regulates APP trans-dimerization and thus its cell adhesion properties and synaptogenic activity. Therefore it is tempting to speculate that the function of trans-interacting APP might dominate under conditions of low neuronal activity or in early steps of synaptogenesis, whereas activity-dependent increase 


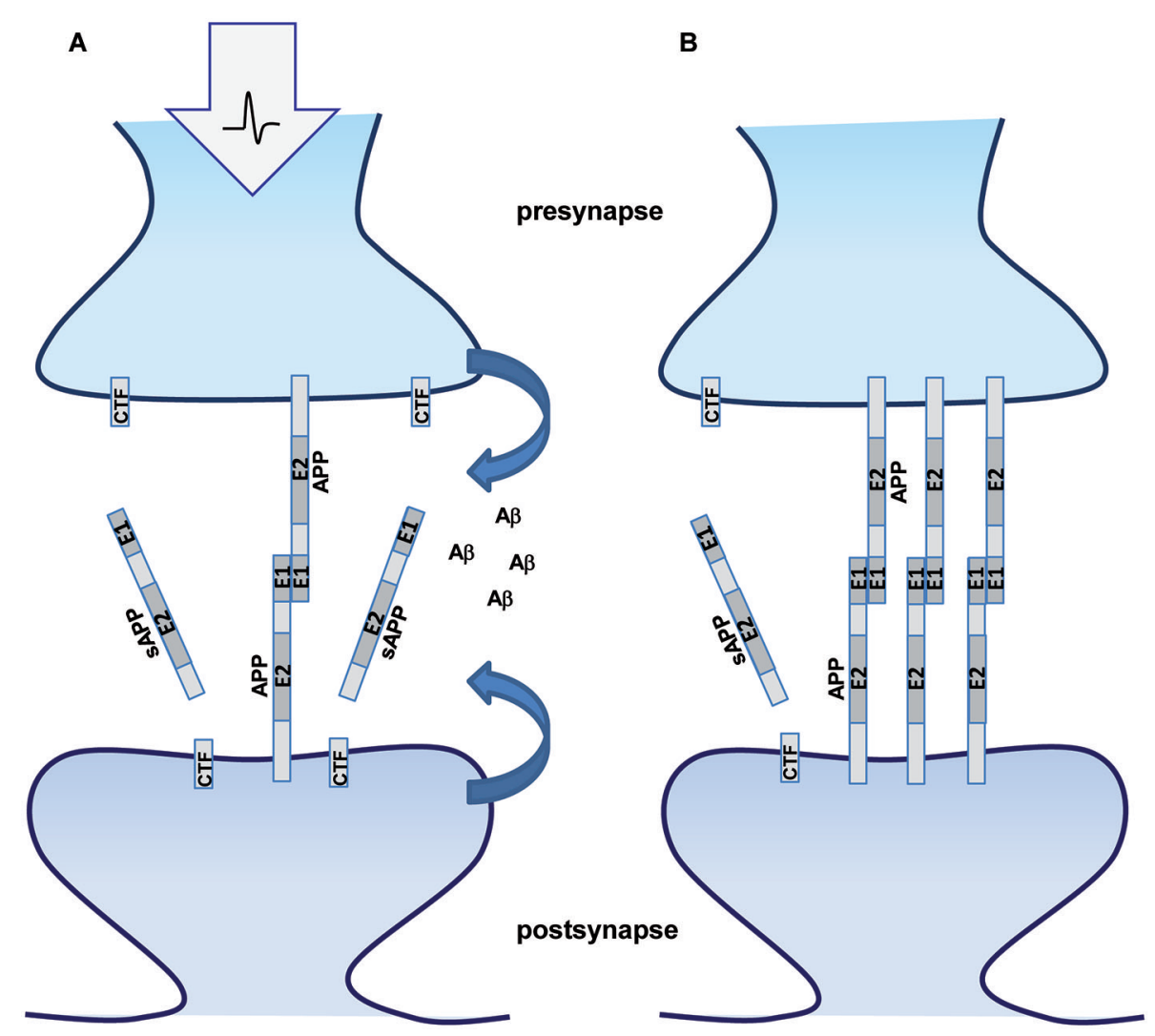

FIGURE 4 | APP processing modulates synaptic function. Schematic representation of APP trans-dimerization and its synaptic function. (A) Enhanced synaptic activity leads to increased APP processing and less intact full length APP available for

trans-dimerization at the synapse. The secreted cleavage product
SAPP $\alpha$ and A $\beta$ might bind different receptors at the pre- and postsynaptic sites modulating neurotransmission and/or synapse formation. (B) Under conditions of low synaptic activity less APP processing occurs and more full length APP will be available for trans-synaptic dimerization. of APP processing might cause a domination of APP cleavage product function (Figure 4). Formation of the chemical synapse is a multi-step process involving target recognition followed by inductive interactions that result in recruitment of a special set of synaptic proteins, such as receptors, signaling molecules and organelles. A large set of diverse synaptic cell adhesion molecules has been implicated in this process, including proto-cadherins, cadherins, neural cell adhesion molecule (NCAM), L1 family CAMs, synaptic immunoglobulin superfamily members, NLG1/Neurexin complexes, Integrin/extra cellular matrix complexes (Dalva et al., 2007; Missler et al., 2012). How this complex network is orchestrated and precisely how APP and its homologs as well as the different cleavage products fit into the SAM machinery will therefore be of high interest for future studies.

\section{MATERIALS AND METHODS}

\section{CLONING OF APP-F615P AND APP $\triangle$ F616 AND - $\triangle$ S622, APP-D8}

pBluescriptSK(+) APP695 NT-myc (Soba et al., 2005) was used as a template and the constructs were generated by PCR using appropriate mutagenesis primer containing a BglII restriction site. For cloning of the different APP constructs the resulting PCR products were ligated into a predigested pSK(+)-APP695 NT-myc vector. The constructs were further subcloned into pUAST and pCEP4 vectors. The identity of all constructs was confirmed by double stranded sequencing.

E1 domain deletion constructs were cloned from the corresponding pUAST-APP-FL clones (pUAST-APP-D8 and pUASTAPP-F615P) with the pUAST-APP $\Delta$ E1 clone (Soba et al., 2005) and pUAST in a three-fragment-ligation. The NotI/EcoRIfragment from pUAST-APPAE1 together with the XhoI/EcoRIfragment of pUAST-APP-D8/-F615P was ligated into NotI/XhoI digested pUAST-vector. The corresponding pUAST clones were digested NotI/EcoRI and EcoRI/XhoI. The two fragments of interest were ligated into NotI/XhoI digested pcDNA3.1-Zeo vector in a three-fragment-ligation.

APP $\triangle 622$ contains a deletion of $A \beta_{\text {minus } 5}-A \beta_{24}$ of the $A \beta$ domain (APP $\triangle 592-621$ ) (APP695 numbering) including the $\beta$-cleavage site at position 1 and the $\alpha$-cleavage site at position 17 within the A $\beta$ sequence. APP $\triangle \mathrm{F} 615$ contains a deletion of sequence $A \beta_{\text {minus5 }}-A \beta_{19}$ within the $A \beta$ domain, which comprises the $\alpha$ - as well as the $\beta$-cleavage site of APP (APP $\triangle 592-621$ ). APP-D8 contains a deletion of sequence $A \beta_{10}-A \beta_{24}$ within the $\mathrm{A} \beta$ domain, which was replaced by eight aspartates, comprising only the $\alpha$-cleavage site. In APP $\Delta \mathrm{E} 1$, the $\mathrm{N}$-terminal sequence aa 
31-192 is deleted. The identity of all constructs was confirmed by double stranded sequencing. The expression vector $\mathrm{pMT}-\mathrm{Kuz}^{\mathrm{DN}}$, encoding a dominant negative form of Kuzbanian was provided by the Drosophila genomic resource center.

\section{ANTIBODIES}

Monoclonal antibodies used in this study: anti-APP 22C11 (epitope hAPP aa 66-81) (Weidemann et al., 1989) for detection of sAPP total. Antibody W02 (Ida et al., 1996) was used for detection of $\operatorname{sAPP} \alpha$. Mouse monoclonal $\beta$-actin antibody was from Sigma. Rabbit Monoclonal antibody against the APP Cterminus (Y188) was from Epitomics. The polyclonal $\operatorname{sAPP} \alpha$ antibody recognizes the ISEVKM sequence at the C-terminus of wild type human sAPP (Immuno-Biological Laboratories, Inc., Minneapolis, MN, USA) (Eggert et al., 2009). Anti-c-myc rabbit polyclonal antibody was from Santa Cruz for detection of cell surface biotinylated proteins. Rabbit polyclonal antibody 22734 with an epitope in the APP ectodomain (Prof. Dr. Multhaup), anti-cmyc, rat (JAC6) (Serotec) was used for detection of myc-tagged proteins via immunocytochemistry. MAP2 rabbit polyclonal antibody was from Santa Cruz, TAU1 mouse monoclonal antibody from Chemicon, Synaptophysin mouse monoclonal antibody was from Sigma, Synaptophysin guinea pig polyclonal from Synaptic systems, SV2 mouse monoclonal antibody from Developmental Studies Hybridoma bank.

For Enhanced Chemical Luminescence (ECL) detection after Western blotting (Pierce), appropriate Horseradish-Peroxidase (HRP) coupled anti-mouse, anti-rabbit, or anti-rat antibodies (Jackson Immunoresearch) were used. Alexa-488, Alexa-594 and Alexa-647 (Molecular Probes) were used as secondary antibodies.

\section{CULTIVATION OF SEMI-ADHERENT SCHNEIDER (S2) CELLS}

S2 cells (Schneider, 1972) were cultivated in T-75 cell culture flasks (Costar) in $20 \mathrm{ml}$ growth medium (Schneider's Medium (Invitrogen), 10\% FBS, 1\% penicillin/streptomycin). S2 cells stayed adherent until 70-80\% confluency was reached, after which they detached and proliferated in suspension. At this time point, cells were passaged by resuspending until a single cell suspension was present. Cells were cultivated at $25^{\circ} \mathrm{C}$ under a normal atmosphere.

\section{TRANSIENT TRANSFECTION OF SCHNEIDER (S2) CELLS}

S2 cells were plated in 12 well dishes at $30-40 \%$ confluency the day before transfection in $2.5 \mathrm{ml}$ total volume. 2-3 $\mathrm{h}$ before transfection, the growth medium was replaced with $800 \mu \mathrm{l}$ of fresh medium, and cells were transfected with Effectene (Qiagen) according to the manufacturer's protocol. In case of cotransfecting several plasmids, equal DNA amounts were used. Expression was induced by adding $\mathrm{CuSO}_{4}\left(0.5 \mathrm{M}\right.$ stock in $\left.\mathrm{ddH}_{2} \mathrm{O}\right)$ to a final concentration of $500 \mu \mathrm{M}$.

\section{ANALYSIS OF SAPP $_{\text {total }}$ SECRETION IN SCHNEIDER CELLS}

Sixteen hour after induction of heterologous protein expression in $\mathrm{S} 2$ cells, medium was replaced by $1 \mathrm{ml}$ fresh medium and conditioned for $3 \mathrm{~h}$. Afterwards, the medium was collected and cleared from cell debris by centrifugation at $10.000 \times \mathrm{g}$ for $10 \mathrm{~min}$. The cells were directly lyzed in $100 \mu l 2 \times$ SDS sample-buffer supplemented with Benzonase (Merck) and denatured at $95^{\circ} \mathrm{C}$ for $5 \mathrm{~min}$. $\mathrm{sAPP}_{\text {total }}$ was immunoprecipitated from the supernatant with an anti-APP antibody (22734, epitope APP ectodomain). Concentrated supernatant and cell-lysate samples were analyzed by SDS-PAGE and immunoblotted with antibody 22C11. Films were digitized and signals were quantified densitometrically using Image Gauge (Fuji Systems). Relative ratios of $\mathrm{sAPP}_{\text {total }}$ compared to cellular APP were calculated for all tested constructs.

\section{SCHNEIDER CELL AGGREGATION ASSAY}

Sixteen hour after induction of heterologous protein expression, S2 cells were centrifuged at $800 \times \mathrm{g}$ for $5 \mathrm{~min}$. The supernatant was replaced by $1 \mathrm{ml}$ fresh growth medium (containing $10 \%$ FCS, 1\% pen/strep) and cells were resuspended to obtain singlecell-suspensions. Cells were counted using a Neubauer Counting Chamber. For analysis, $4 \times 10^{5}$ cells in single cell suspension were aggregated in a total volume of $1 \mathrm{ml}$ fresh growth medium in a 24 -well plate for $2 \mathrm{~h}$ at $90 \mathrm{rpm}$ on a horizontal shaker (Greiner 24-well suspension culture dish). Afterwards, cells were transferred to poly-L-lysine coated cover slips and allowed to attach for 2-3 h. Aggregated Schneider cells were further processed by immunocytochemistry.

\section{IMMUNOCYTOCHEMISTRY AND QUANTIFICATION OF AGGREGATED S2 CELLS}

Aggregated S2 cells attached to cover slips were fixed in $4 \%$ PFA for $10 \mathrm{~min}$. Cells were washed three times with PBS and permeabilized with $0.1 \%$ NP40/PBS for $10 \mathrm{~min}$. Afterwards, cells were washed again three times in PBS, blocked with 5\% normal goat serum in PBS for $1 \mathrm{~h}$ and stained over night at $4^{\circ} \mathrm{C}$ with a rat anti-c-myc-antibody (JAC6, Serotec). Anti-rat AlexaFluor488 (Invitrogen) was used as secondary antibody for $1 \mathrm{~h}$ at room temperature. After extensive washing, cells were embedded in Mowiol.

For quantification of aggregated cells, clusters of three or more transfected cells were scored as positive. In total, 5001100 transfected cells from at least five independent experiments were counted for each experimental setup in a blinded fashion. Clusters of non-transfected cells were not counted. The average transfection efficiency varied between $10 \%$ and $30 \%$. To minimize variation, only experiments with similar transfection rates $(+/-$ $10 \%)$ were compared with each other. Statistical significance of all quantified experiments was tested with a Students $T$-test, $p<0.05$ was designated as significant, $p<0.001$ as highly significant.

\section{CO-CULTURE ASSAY}

Co-cultures of HEK293 cells and neurons were performed essentially as described (Biederer and Scheiffele, 2007). HEK293 cells were cultured in DMEM-High glucose supplemented with $10 \%$ fetal bovine serum and 1\% Pen/Strep. Cortical neuron cultures were prepared from E14 mouse embryos (C57/Bl6J) according to previously described protocols (Biederer and Scheiffele, 2007). Briefly, cortices were dissected in ice cold HBSS supplemented with $10 \mathrm{mM}$ HEPES. After a $15 \mathrm{~min}$ incubation time at $37^{\circ} \mathrm{C}$ in $0.05 \%$ Trypsin-EDTA, the cortices were washed five times in $1 \times$ HBSS and triturated with a pasteur pipette. The dissociated cells were resuspended in DB1 media [DMEM with 10\% (v/v) 
FCS, $0.79 \%(\mathrm{w} / \mathrm{v})$ D-glucose, and $2 \mathrm{mM}$ glutamine] and plated onto $14 \mathrm{~mm}$ coverslips pretreated with poly-L-lysine $(20 \mu \mathrm{g} / \mathrm{ml}$ in borate buffer). After $6 \mathrm{~h}$, the media was replaced with NM media (Neurobasal medium with $2 \%(\mathrm{v} / \mathrm{v})$ B-27 supplement, and 2 mM Glutamax). At DIV 6 of the neuronal culture, HEK293 cells were transfected with jetPRIME (Polyplus) according to manufacturer's instructions. GFP pcDNA3.1+ was used as a negative control, NLG-1-1 HA pcDNA3.1+ as a positive control. Constructs NT my APP695 wt, NT my APP695 D8 pcDNA3.1+ and NT my APP695 $\Delta 622$ pcDNA3.1+ were analyzed in addition. Twentyfour hours later, transfected cells were seeded onto the cultured primary neurons (DIV7). After $24 \mathrm{~h}$ (DIV8), the cultures were fixed in $4 \%(\mathrm{w} / \mathrm{v})$ PFA/PBS supplemented with $4 \%(\mathrm{w} / \mathrm{v})$ sucrose, permeabilized in $0.1 \% \mathrm{NP} 401 \times \mathrm{PBS}$. The potentially synapse inducing proteins expressed in HEK293 cells were detected with anti-c-my (1:200, Serotec) and anti-HA (1:300, Roche) antibodies (secondary antibody Alexa-Flour 488, Invitrogen). In addition the cultures were stained with the presynaptic marker Synaptophysin (1:200, Sigma) to visualize the synaptic puncta (secondary antibody Alexa-Flour 594, Invitrogen). Changes in the number of synaptic puncta or the area covered by synaptic puncta were used as a readout of induced presynaptic differentiation. Furthermore, antibody MAP2 (Santa Cruz) was used as a dendritic marker to ensure correct quantitative analysis of HEK293/axonal contacts. Only Synaptophysin puncta at MAP2 negative HEK cells were analyzed at so called hemisynapses between HEK cells and axons, not dendrites and axons. Z-stack images were taken with the microscope Axio Observer Z.1 (Zeiss) (apotome) and quantification was performed via ImageJ analysis according to an already established protocol (Fogel et al., 2007). Statistical analysis was performed with one-way factorial ANOVA followed by Tukey's post hoc analyses $\left(n \geq 4\right.$; $^{*} p<0.05$; ** $p<0.01$; *** $\left.p<0.001\right)$. Results are presented as mean \pm SEM.

\section{CELL SURFACE BIOTINYLATION}

HEK293 cells were seeded in a 6 well plate at a density of $3 \times$ $10^{5}$ cells per well and transfected the following day with Lipofectamine 2000 (Invitrogen) according to manufacturer's instructions. To examine surface levels of APP, cells were rinsed two times with ice cold $1 \times$ PBS. Cell surface proteins were biotinylated with $1 \mathrm{ml}$ EZ-Link Sulfo-NHS-LC-Biotin (Pierce) $(2 \mathrm{mg} / \mathrm{ml})$ in ice cold PBS for $30 \mathrm{~min}$ at $4^{\circ} \mathrm{C}$. Cells were washed three times with ice-cold $1 \times$ PBS containing $100 \mathrm{mM}$ glycine to quench unconjugated biotin and lyzed in $1 \times$ RIPA buffer $(20 \mathrm{mM}$ Tris/ $\mathrm{HCl}$ $\mathrm{pH}$ 8.0, $150 \mathrm{mM} \mathrm{NaCl}, 1 \% \mathrm{NP}-40$ (w/v), 0.5\% deoxycholate, $5 \mathrm{mM}$ EDTA pH 8.0, 0.1\% SDS.) including protease inhibitors (Roche). $20 \mu \mathrm{g}$ protein of cell lysate was used for the direct load. Equal amounts of protein were incubated with NeutrAvidin Agarose Resin (Pierce) over night at $4^{\circ} \mathrm{C}$. Biotinylated proteins were recovered by boiling in $2 \times$ sample buffer with DTT for $5 \mathrm{~min}$ at $95^{\circ} \mathrm{C}$ and separated on $8 \%$ Tris/glycine gels and detected with antibody c-myc.

\section{ANALYSIS OF APP PROCESSING IN HEK293 CELLS}

HEK293 cells were cultured in DMEM-high glucose supplemented with $10 \%$ FBS and 1\% penicillin/streptomycin and seeded in a 6 well plate at a density of $3 \times 10^{5}$ cells per well and transfected the following day with Lipofectamine 2000 (Invitrogen) according to manufacturer's instructions. Medium was changed after $4 \mathrm{~h}$ and conditioned for $17 \mathrm{~h}$ overnight. For analysis the media was centrifuged for $10 \mathrm{~min}$ at $13.000 \times \mathrm{g}$ at $4^{\circ} \mathrm{C}$. The supernatant was used for analysis of $\mathrm{sAPP}_{\text {total }}, \operatorname{sAPP} \alpha, \operatorname{sAPP} \beta$ by Western Blot with the respective antibodies.

The cells were harvested in ice cold $1 \times$ PBS and subsequently incubated for $15 \mathrm{~min}$ in lysis buffer $(50 \mathrm{mM}$ Tris/ $\mathrm{HCl}, \mathrm{pH} 7.5$, $150 \mathrm{mM} \mathrm{NaCl}, 5 \mathrm{mM}$ EDTA, and 1\% Nonidet P40) supplemented with protease inhibitors (Roche) at $4^{\circ} \mathrm{C}$. After a $10 \mathrm{~min}$ centrifugation step at $12.000 \times \mathrm{g}$ at $4^{\circ} \mathrm{C}$, the supernatants were collected and the protein concentration was determined with a BCA assay (Sigma). Equal amounts of protein were separated by PAGE and subjected to Western Blot analysis of full length APP. Densitometric quantification of the Western Blots was performed with Image J software. Statistical analysis was performed with one-way factorial ANOVA followed by Tukey's post hoc analyses $\left(n \geq 5\right.$; $^{*} p<0.05$; ** $p<0.01$; $\left.{ }^{* * *} p<0.001\right)$. Results are presented as mean \pm SEM.

\section{AUTHOR CONTRIBUTIONS}

Ronny Stahl, Sandra Schilling, Peter Soba, Carsten Rupp, Katja Wagner performed different experiments and analyzed the data. Tobias Hartmann, Gunter Merdes provided material and analyzed data. Simone Eggert and Stefan Kins designed experiments, wrote the manuscript.

\section{ACKNOWLEDGMENTS}

Stefan Kins acknowledges support by the Deutsche Forschungsgemeinschaft (DFG) and BioComp Forschungsschwerpunkt Rheinland-Pfalz. We thank Prof. Dr. Gerd Multhaup for kindly providing the 22734 antibody against APP. We thank Dagmar Gross for excellent technical assistance and Prof. Dr. Peter Scheiffele for kindly providing NLG 1 cDNA.

\section{REFERENCES}

Araki, Y., Miyagi, N., Kato, N., Yoshida, T., Wada, S., Nishimura, M., et al. (2004). Coordinated metabolism of Alcadein and amyloid beta-protein precursor regulates FE65-dependent gene transactivation. J. Biol. Chem. 279, 24343-24354. doi: 10.1074/jbc.m401925200

Back, S., Haas, P., Tschäpe, J. A., Gruebl, T., Kirsch, J., Müller, U., et al. (2007). $\beta$-amyloid precursor protein can be transported independent of any sorting signal to the axonal and dendritic compartment. J. Neurosci. Res. 85, 2580-2590. doi: 10.1002/jnr.21239

Baumkötter, F., Schmidt, N., Vargas, C., Schilling, S., Weber, R., Wagner, K., et al. (2014). Amyloid precursor protein dimerization and synaptogenic function depend on copper binding to the growth factor-like domain. J. Neurosci. 34, 11159-11172. doi: 10.1523/JNEUROSCI.0180-14.2014

Baumkötter, F., Wagner, K., Eggert, S., Wild, K., and Kins, S. (2012). Structural aspects and physiological consequences of APP/APLP trans-dimerization. Exp. Brain Res. 217, 389-395. doi: 10.1007/s00221-011-2878-6

Biederer, T., and Scheiffele, P. (2007). Mixed-culture assays for analyzing neuronal synapse formation. Nat. Protoc. 2, 670-676. doi: 10.1038/nprot.2007.92

Carmine-Simmen, K., Proctor, T., Tschäpe, J., Poeck, B., Triphan, T., Strauss, R., et al. (2009). Neurotoxic effects induced by the Drosophila amyloid-beta peptide suggest a conserved toxic function. Neurobiol. Dis. 33, 274-281. doi: 10.1016/j. nbd.2008.10.014

Dahms, S. O., Hoefgen, S., Roeser, D., Schlott, B., Gührs, K. H., and Than, M. E. (2010). Structure and biochemical analysis of the heparin-induced E1 dimer of the amyloid precursor protein. Proc. Natl. Acad. Sci. U S A 107, 5381-5386. doi: 10.1073/pnas.0911326107 
Dalva, M. B., McClelland, A. C., and Kayser, M. S. (2007). Cell adhesion molecules: signalling functions at the synapse. Nat. Rev. Neurosci. 8, 206-220. doi: 10. 1038/nrn2075

Eggert, S., Midthune, B., Cottrell, B., and Koo, E. H. (2009). Induced dimerization of the amyloid precursor protein leads to decreased amyloid-beta protein production. J. Biol. Chem. 284, 28943-28952. doi: 10.1074/jbc.M109.038646

Esch, F. S., Keim, P. S., Beattie, E. C., Blacher, R. W., Culwell, A. R., Oltersdorf, T., et al. (1990). Cleavage of amyloid beta peptide during constitutive processing of its precursor. Science 248, 1122-1124. doi: 10.1126/science.2111583

Farber, S. A., Nitsch, R. M., Schulz, J. G., and Wurtman, R. J. (1995). Regulated secretion of beta-amyloid precursor protein in rat brain. J. Neurosci. 15, 74427451.

Fogel, A. I., Akins, M. R., Krupp, A. J., Stagi, M., Stein, V., and Biederer, T. (2007). SynCAMs organize synapses through heterophilic adhesion. J. Neurosci. 27, 12516-12530. doi: 10.1523/jneurosci.2739-07.2007

Furukawa, K., and Mattson, M. P. (1998). Secreted amyloid precursor protein alpha selectively suppresses N-methyl-D-aspartate currents in hippocampal neurons: involvement of cyclic GMP. Neuroscience 83, 429-438. doi: 10.1016/s03064522(97)00398-9

Graf, E. R., Zhang, X., Jin, S. X., Linhoff, M. W., and Craig, A. M. (2004). Neurexins induce differentiation of GABA and glutamate postsynaptic specializations via neuroligins. Cell 119, 1013-1026. doi: 10.1016/j.cell.2004.11.035

Herms, J., Anliker, B., Heber, S., Ring, S., Fuhrmann, M., Kretzschmar, H., et al. (2004). Cortical dysplasia resembling human type 2 lissencephaly in mice lacking all three APP family members. EMBO J. 23, 4106-4115. doi: 10.1038/sj. emboj.7600390

Hoe, H. S., Lee, K. J., Carney, R. S., Lee, J., Markova, A., Lee, J. Y., et al. (2009). Interaction of reelin with amyloid precursor protein promotes neurite outgrowth. J. Neurosci. 29, 7459-7473. doi: 10.1523/JNEUROSCI.4872-08.2009

Hundhausen, C., Misztela, D., Berkhout, T. A., Broadway, N., Saftig, P., Reiss, K., et al. (2003). The disintegrin-like metalloproteinase ADAM10 is involved in constitutive cleavage of CX3CL1 (fractalkine) and regulates CX3CL1-mediated cell-cell adhesion. Blood 102, 1186-1195. doi: 10.1182/blood-2002-12-3775

Ida, N., Hartmann, T., Pantel, J., Schröder, J., Zerfass, R., Forstl, H., et al. (1996). Analysis of heterogeneous A4 peptides in human cerebrospinal fluid and blood by a newly developed sensitive Western blot assay. J. Biol. Chem. 271, 2290822914. doi: 10.1074/jbc.271.37.22908

Islam, R., Kristiansen, L. V., Romani, S., Garcia-Alonso, L., and Hortsch, M. (2004). Activation of EGF receptor kinase by L1-mediated homophilic cell interactions. Mol. Biol. Cell 15, 2003-2012. doi: 10.1091/mbc.e03-05-0333

Jacobsen, K. T., and Iverfeldt, K. (2009). Amyloid precursor protein and its homologues: a family of proteolysis-dependent receptors. Cell. Mol. Life Sci. 66, 2299-2318. doi: 10.1007/s00018-009-0020-8

Kaden, D., Voigt, P., Munter, L. M., Bobowski, K. D., Schaefer, M., and Multhaup, G. (2009). Subcellular localization and dimerization of APLP1 are strikingly different from APP and APLP2. J. Cell Sci. 122, 368-377. doi: 10.1242/jcs.034058

Kakuda, N., Funamoto, S., Yagishita, S., Takami, M., Osawa, S., Dohmae, N., et al. (2006). Equimolar production of amyloid beta-protein and amyloid precursor protein intracellular domain from beta-carboxyl-terminal fragment by gammasecretase. J. Biol. Chem. 281, 14776-14786. doi: 10.1074/jbc.m513453200

Kamenetz, F., Tomita, T., Hsieh, H., Seabrook, G., Borchelt, D., Iwatsubo, T., et al. (2003). APP processing and synaptic function. Neuron 37, 925-937. doi: 10. 1016/s0896-6273(03)00124-7

Kang, J., Lemaire, H. G., Unterbeck, A., Salbaum, J. M., Masters, C. L., Grzeschik, K. H., et al. (1987). The precursor of Alzheimer's disease amyloid A4 protein resembles a cell-surface receptor. Nature 325, 733-736. doi: 10.1038/325733a0

Kim, T. W., Wu, K., Xu, J. L., McAuliffe, G., Tanzi, R. E., Wasco, W., et al. (1995). Selective localization of amyloid precursor-like protein 1 in the cerebral cortex postsynaptic density. Brain Res. Mol. Brain Res. 32, 36-44. doi: 10.1016/0169$328 \mathrm{x}(95) 00328-\mathrm{p}$

Klueg, K. M., and Muskavitch, M. A. (1999). Ligand-receptor interactions and trans-endocytosis of Delta, Serrate and Notch: members of the Notch signalling pathway in Drosophila. J. Cell Sci. 112, 3289-3297.

Kotani, N., Kitazume, S., Kamimura, K., Takeo, S., Aigaki, T., Nakato, H., et al. (2005). Characterization of Drosophila aspartic proteases that induce the secretion of a Golgi-resident transferase, heparan sulfate 6-O-sulfotransferase. J. Biochem. 137, 315-322. doi: 10.1093/jb/mvi034

Kuhn, P. H., Wang, H., Dislich, B., Colombo, A., Zeitschel, U., Ellwart, J. W., et al. (2010). ADAM10 is the physiologically relevant, constitutive alpha-secretase of the amyloid precursor protein in primary neurons. EMBO J. 29, 3020-3032. doi: 10.1038/emboj.2010.167

Lammich, S., Kojro, E., Postina, R., Gilbert, S., Pfeiffer, R., Jasionowski, M., et al. (1999). Constitutive and regulated alpha-secretase cleavage of Alzheimer's amyloid precursor protein by a disintegrin metalloprotease. Proc. Natl. Acad. Sci. U S A 96, 3922-3927. doi: 10.1073/pnas.96.7.3922

Lee, K. J., Moussa, C. E., Lee, Y., Sung, Y., Howell, B. W., Turner, R. S., et al. (2010). Beta amyloid-independent role of amyloid precursor protein in generation and maintenance of dendritic spines. Neuroscience 169, 344-356. doi: 10.1016/j. neuroscience.2010.04.078

Luo, L. Q., Martin-Morris, L. E., and White, K. (1990). Identification, secretion and neural expression of APPL, a Drosophila protein similar to human amyloid protein precursor. J. Neurosci. 10, 3849-3861.

Lyckman, A. W., Confaloni, A. M., Thinakaran, G., Sisodia, S. S., and Moya, K. L. (1998). Post-translational processing and turnover kinetics of presynaptically targeted amyloid precursor superfamily proteins in the central nervous system. J. Biol. Chem. 273, 11100-11106. doi: 10.1074/jbc.273.18.11100

Maretzky, T., Reiss, K., Ludwig, A., Buchholz, J., Scholz, F., Proksch, E., et al. (2005). ADAM10 mediates E-cadherin shedding and regulates epithelial cellcell adhesion, migration and beta-catenin translocation. Proc. Natl. Acad. Sci. U S A 102, 9182-9187. doi: 10.1073/pnas.0500918102

Maruyama, K., Kametani, F., Usami, M., Yamao-Harigaya, W., and Tanaka, K. (1991). "Secretase," Alzheimer amyloid protein precursor secreting enzyme is not sequence-specific. Biochem. Biophys. Res. Commun. 179, 1670-1676. doi: 10. 1016/0006-291x(91)91767-7

Masters, C. L., Simms, G., Weinman, N. A., Multhaup, G., McDonald, B. L., and Beyreuther, K. (1985). Amyloid plaque core protein in Alzheimer disease and down syndrome. Proc. Natl. Acad. Sci. U S A 82, 4245-4249. doi: 10.1073/pnas. 82.12.4245

Miles, L. A., Wun, K. S., Crespi, G. A., Fodero-Tavoletti, M. T., Galatis, D., Bagley, C. J., et al. (2008). Amyloid-beta-anti-amyloid-beta complex structure reveals an extended conformation in the immunodominant B-cell epitope. J. Mol. Biol. 377, 181-192. doi: 10.1016/j.jmb.2007.12.036

Missler, M., Südhof, T. C., and Biederer, T. (2012). Synaptic cell adhesion. Cold Spring Harb. Perspect. Biol. 4:a005694. doi: 10.1101/cshperspect.a005694

Moechars, D., Lorent, K., De Strooper, B., Dewachter, I., and Van Leuven, F. (1996). Expression in brain of amyloid precursor protein mutated in the alpha-secretase site causes disturbed behavior, neuronal degeneration and premature death in transgenic mice. EMBO J. 15, 1265-1274.

Moechars, D., Lorent, K., Dewachter, I., Baekelandt, V., De Strooper, B., and Van Leuven, F. (1998). Transgenic mice expressing an alpha-secretion mutant of the amyloid precursor protein in the brain develop a progressive CNS disorder. Behav. Brain Res. 95, 55-64. doi: 10.1016/s0166-4328(97)00210-6

Müller, U., Cristina, N., Li, Z. W., Wolfer, D. P., Lipp, H. P., Rulicke, T., et al. (1994). Behavioral and anatomical deficits in mice homozygous for a modified beta-amyloid precursor protein gene. Cell 79, 755-765. doi: 10.1016/00928674(94)90066-3

Müller, U. C., and Zheng, H. (2012). Physiological functions of APP family proteins. Cold Spring Harb. Perspect. Med. 2:a006288. doi: 10.1101/cshperspect. a006288

Pan, D., and Rubin, G. M. (1997). Kuzbanian controls proteolytic processing of Notch and mediates lateral inhibition during Drosophila and vertebrate neurogenesis. Cell 90, 271-280. doi: 10.1016/s0092-8674(00)80335-9

Pettem, K. L., Yokomaku, D., Luo, L., Linhoff, M. W., Prasad, T., Connor, S. A., et al. (2013). The specific $\alpha$-neurexin interactor calsyntenin-3 promotes excitatory and inhibitory synapse development. Neuron $80,113-128$. doi: 10.1016/j. neuron.2013.07.016

Phinney, A. L., Calhoun, M. E., Wolfer, D. P., Lipp, H. P., Zheng, H., and Jucker, M. (1999). No hippocampal neuron or synaptic bouton loss in learning-impaired aged beta-amyloid precursor protein-null mice. Neuroscience 90, 1207-1216. doi: 10.1016/s0306-4522(98)00645-9

Poeck, B., Strauss, R., and Kretzschmar, D. (2012). Analysis of amyloid precursor protein function in Drosophila melanogaster. Exp. Brain Res. 217, 413-421. doi: 10.1007/s00221-011-2860-3

Prox, J., Bernreuther, C., Altmeppen, H., Grendel, J., Glatzel, M., D’hooge, R., et al. (2013). Postnatal disruption of the disintegrin/metalloproteinase ADAM10 in brain causes epileptic seizures, learning deficits, altered spine morphology and defective synaptic functions. J. Neurosci. 33, 12915-12928. doi: 10. 1523/JNEUROSCI.5910-12.2013 
Reinhard, C., Hébert, S. S., and De Strooper, B. (2005). The amyloid-beta precursor protein: integrating structure with biological function. EMBO J. 24, 3996-4006. doi: 10.1038/sj.emboj.7600860

Ring, S., Weyer, S. W., Kilian, S. B., Waldron, E., Pietrzik, C. U., Filippov, M. A., et al. (2007). The secreted beta-amyloid precursor protein ectodomain APPs alpha is sufficient to rescue the anatomical, behavioral and electrophysiological abnormalities of APP-deficient mice. J. Neurosci. 27, 7817-7826. doi: 10. 1523/jneurosci.1026-07.2007

Rooke, J., Pan, D., Xu, T., and Rubin, G. M. (1996). KUZ, a conserved metalloprotease-disintegrin protein with two roles in Drosophila neurogenesis. Science 273, 1227-1231. doi: 10.1126/science.273.5279.1227

Sahasrabudhe, S. R., Spruyt, M. A., Muenkel, H. A., Blume, A. J., Vitek, M. P., and Jacobsen, J. S. (1992). Release of amino-terminal fragments from amyloid precursor protein reporter and mutated derivatives in cultured cells. J. Biol. Chem. 267, 25602-25608.

Scheiffele, P., Fan, J., Choih, J., Fetter, R., and Serafini, T. (2000). Neuroligin expressed in nonneuronal cells triggers presynaptic development in contacting axons. Cell 101, 657-669. doi: 10.1016/s0092-8674(00)80877-6

Schneider, I. (1972). Cell lines derived from late embryonic stages of Drosophila melanogaster. J. Embryol. Exp. Morphol. 27, 353-365.

Seabrook, G. R., Smith, D. W., Bowery, B. J., Easter, A., Reynolds, T., Fitzjohn, S. M., et al. (1999). Mechanisms contributing to the deficits in hippocampal synaptic plasticity in mice lacking amyloid precursor protein. Neuropharmacology 38, 349-359. doi: 10.1016/s0028-3908(98)00204-4

Siddiqui, T. J., and Craig, A. M. (2011). Synaptic organizing complexes. Curr. Opin. Neurobiol. 21, 132-143. doi: 10.1016/j.conb.2010.08.016

Sisodia, S. S. (1992). Beta-amyloid precursor protein cleavage by a membranebound protease. Proc. Natl. Acad. Sci. U S A 89, 6075-6079. doi: 10.1073/pnas. 89.13.6075

Six, E., Ndiaye, D., Laabi, Y., Brou, C., Gupta-Rossi, N., Israel, A., et al. (2003). The Notch ligand Deltal is sequentially cleaved by an ADAM protease and gamma-secretase. Proc. Natl. Acad. Sci. US A 100, 7638-7643. doi: 10.1073/pnas. 1230693100

Soba, P., Eggert, S., Wagner, K., Zentgraf, H., Siehl, K., Kreger, S., et al. (2005). Homo- and heterodimerization of APP family members promotes intercellular adhesion. EMBO J. 24, 3624-3634. doi: 10.1038/sj.emboj.7600824

Solans, A., Estivill, X., and de La Luna, S. (2000). A new aspartyl protease on 21q22.3, BACE2, is highly similar to Alzheimer's amyloid precursor protein beta-secretase. Cytogenet. Cell Genet. 89, 177-184. doi: 10.1159/0000 15608

Soldano, A., and Hassan, B. A. (2014). Beyond pathology: APP, brain development and Alzheimer's disease. Curr. Opin. Neurobiol. 27C, 61-67. doi: 10.1016/j.conb. 2014.02.003

Sudhof, T. C. (2008). Neuroligins and neurexins link synaptic function to cognitive disease. Nature 455, 903-911. doi: 10.1038/nature07456

Suzuki, K., Hayashi, Y., Nakahara, S., Kumazaki, H., Prox, J., Horiuchi, K., et al. (2012). Activity-dependent proteolytic cleavage of neuroligin-1. Neuron 76 , 410-422. doi: 10.1016/j.neuron.2012.10.003

Taylor, C. J., Ireland, D. R., Ballagh, I., Bourne, K., Marechal, N. M., Turner, P. R., et al. (2008). Endogenous secreted amyloid precursor protein-alpha regulates hippocampal NMDA receptor function, long-term potentiation and spatial memory. Neurobiol. Dis. 31, 250-260. doi: 10.1016/j.nbd.2008. 04.011

Tsiotra, P. C., Theodorakis, K., Papamatheakis, J., and Karagogeos, D. (1996). The fibronectin domains of the neural adhesion molecule TAX-1 are necessary and sufficient for homophilic binding. J. Biol. Chem. 271, 29216-29222. doi: 10. 1074/jbc.271.46.29216

Tyan, S. H., Shih, A. Y., Walsh, J. J., Maruyama, H., Sarsoza, F., Ku, L., et al. (2012). Amyloid precursor protein (APP) regulates synaptic structure and function. Mol. Cell. Neurosci. 51, 43-52. doi: 10.1016/j.mcn.2012.07.009
Vassar, R., Bennett, B. D., Babu-Khan, S., Kahn, S., Mendiaz, E. A., Denis, P., et al. (1999). Beta-secretase cleavage of Alzheimer's amyloid precursor protein by the transmembrane aspartic protease BACE. Science 286, 735-741. doi: 10. $1126 /$ science. 286.5440 .735

Walsh, D. M., Minogue, A. M., Sala Frigerio, C., Fadeeva, J. V., Wasco, W., and Selkoe, D. J. (2007). The APP family of proteins: similarities and differences. Biochem. Soc. Trans. 35, 416-420. doi: 10.1042/bst0350416

Wang, Z., Wang, B., Yang, L., Guo, Q., Aithmitti, N., Songyang, Z., et al. (2009). Presynaptic and postsynaptic interaction of the amyloid precursor protein promotes peripheral and central synaptogenesis. J. Neurosci. 29, 10788-10801. doi: 10.1523/JNEUROSCI.2132-09.2009

Wang, P., Yang, G., Mosier, D. R., Chang, P., Zaidi, T., Gong, Y. D., et al. (2005). Defective neuromuscular synapses in mice lacking amyloid precursor protein (APP) and APP-Like protein 2. J. Neurosci. 25, 1219-1225. doi: 10. 1523/jneurosci.4660-04.2005

Weidemann, A., Eggert, S., Reinhard, F. B., Vogel, M., Paliga, K., Baier, G., et al. (2002). A novel $\epsilon$-cleavage within the transmembrane domain of the Alzheimer amyloid precursor protein demonstrates homology with Notch processing. Biochemistry 41, 2825-2835. doi: 10.1021/bi015794o

Weidemann, A., König, G., Bunke, D., Fischer, P., Salbaum, J. M., Masters, C. L., et al. (1989). Identification, biogenesis and localization of precursors of Alzheimer's disease A4 amyloid protein. Cell 57, 115-126. doi: 10.1016/00928674(89)90177-3

Weyer, S. W., Klevanski, M., Delekate, A., Voikar, V., Aydin, D., Hick, M., et al. (2011). APP and APLP2 are essential at PNS and CNS synapses for transmission, spatial learning and LTP. EMBO J. 30, 2266-2280. doi: 10.1038/emboj. 2011.119

Weyer, S. W., Zagrebelsky, M., Herrmann, U., Hick, M., Ganss, L., Gobbert, J., et al. (2014). Comparative analysis of single and combined APP/APLP knockouts reveals reduced spine density in APP-KO mice that is prevented by APPsalpha expression. Acta Neuropathol. Commun. 2:36. doi: 10.1186/2051-5960-2-36

Wilhelm, B. G., Mandad, S., Truckenbrodt, S., Kröhnert, K., Schäfer, C., Rammner, B., et al. (2014). Composition of isolated synaptic boutons reveals the amounts of vesicle trafficking proteins. Science 344, 1023-1028. doi: 10.1126/science. 1252884

Young-Pearse, T. L., Bai, J., Chang, R., Zheng, J. B., LoTurco, J. J., and Selkoe, D. J. (2007). A critical function for beta-amyloid precursor protein in neuronal migration revealed by in utero RNA interference. J. Neurosci. 27, 14459-14469. doi: 10.1523/jneurosci.4701-07.2007

Zhong, Z., Higaki, J., Murakami, K., Wang, Y., Catalano, R., Quon, D., et al. (1994). Secretion of beta-amyloid precursor protein involves multiple cleavage sites. $J$. Biol. Chem. 269, 627-632.

Conflict of Interest Statement: The authors declare that the research was conducted in the absence of any commercial or financial relationships that could be construed as a potential conflict of interest.

Received: 30 October 2014; accepted: 11 November 2014; published online: 03 December 2014.

Citation: Stahl R, Schilling S, Soba P, Rupp C, Hartmann T, Wagner K, Merdes G, Eggert $S$ and Kins $S$ (2014) Shedding of APP limits its synaptogenic activity and cell adhesion properties. Front. Cell. Neurosci. 8:410. doi: 10.3389/fncel.2014.00410 This article was submitted to the journal Frontiers in Cellular Neuroscience. Copyright (c) 2014 Stahl, Schilling, Soba, Rupp, Hartmann, Wagner, Merdes, Eggert and Kins. This is an open-access article distributed under the terms of the Creative Commons Attribution License (CC BY). The use, distribution and reproduction in other forums is permitted, provided the original author(s) or licensor are credited and that the original publication in this journal is cited, in accordance with accepted academic practice. No use, distribution or reproduction is permitted which does not comply with these terms. 